УДК 543.63:001.891.53

\title{
Determination of chlorogenic acids in carrots during storage
}

\author{
T. M. SHACHEK ${ }^{1}$, T. I. MARCHANKAVA ${ }^{2}$, E. N. ZELENKOVA ${ }^{3}$ \\ ${ }^{1}$ shachek@tut.by, ${ }^{2}$ marchelitta@tut.by, ${ }^{3}$ elena.taras@mail.ru \\ Belarusian State Technological University
}

In this paper the results of quantitative analysis of chlorogenic acids in selected carrot cultivars grown in Belarus are presented. Fresh and stored carrot roots of the Dordogne, Narbona and Chantane cultivars (harvested in 2016) were used for the research. Varietal differences in accumulation of the phenolic compounds under investigation were established. The original photometric method was used for the quantitative determination of hydroxycinnamic acids in fresh carrots. The method was modified at the stages of sample preparation (sample weight) and preparation of the analyte (volume of the solution being analyzed). Validation experiment showed the stability and accuracy of the technique, metrological characteristics being assessed: repeatability (convergence) $-5.59 \%$, reproducibility (intralaboratory) $-19.97 \%$, and linearity in the concentration range of chlorogenic acids - from 20.0 to $80.0 \mathrm{mg} / 100 \mathrm{~g} \mathrm{DW}$. The dynamics of hydroxycinnamic acids during the storage of raw materials both in regulated $-0 \pm 1{ }^{\circ} \mathrm{C}$ and unregulated conditions $-4 \pm 6^{\circ} \mathrm{C}$ was studied. Accumulation of hydroxycinnamic acids was significant (up to $263 \%$ ) when storing carrots under standard conditions and the influence of unregulated conditions on the intensity of hydroxycinnamic acids accumulation was established. On the basis the of research literature analysis, the biological activity of chlorogenic acids, as the main representatives of hydroxycinnamic acids in plant raw materials, was studied. It was shown that the dynamics of these substances in carrots during storage is actual to study. Keywords: carrot, cultivar, hydroxycinnamic acids, analysis, validation, metrological characteristics, chlorogenic acid, the initial level in roots, storage of carrots, dynamics of biologically active substances.

\section{Article info:}

Received 23/10/2017, accepted 24/11/2017

DOI: $10.21047 / 1606-4313-2017-16-4-3-8$

Article in Russian

For citation:

Shachek T. M., Marchankava T. I., Zelenkova E. N. Determination of chlorogenic acids in carrots during storage. Vestnik Mezhdunarodnoi akademii kholoda. 2017. No 4. p. 3-8.

\section{Определение хлорогеновых кислот в моркови при ее хранении}

\author{
Канд. техн. наук Т. М. ШАЧЕК ${ }^{1}$, Т. И. МАРЧЕНКОВА ${ }^{2}$ Е. Н. ЗЕЛЕНКОВА ${ }^{3}$ \\ 'shachek@tut.by, ${ }^{2}$ marchelitta@tut.by, ${ }^{3}$ elena.taras@mail.ru \\ Белорусский государственный технологический университет
}

Представлены результаты оценки хранившихся корнеплодов моркови сортов белорусской зоны произрастания по содержсанию хлорогеновых кислот. Объектами исследования являлись свежеубранные и хранившиеся корнеплоды моркови ботанических сортов Дордонь, Нарбона и Шантане урожая 2016 г. Установлены сортовые различия в накоплении изучаемых фенольных соединений. Для исследований использовали оригинальную фотометрическую методику, модифицированную в части массы исходной пробы и объема анализируемого раствора для количественного определения оксикоричных кислот в свежей моркови. Пригодность данной методики подтверждена в валидационном эксперименте при оценке ее метрологических характеристик: повторяемость (сходимость) 5,59\%, воспроизводмость (внутрилабораторная) - 19,97\% и линейность в диапазоне концентраций хлорогеновых кислот - от 20,0 до 80,0 мг/100 г СВ. Динамику оксикоричных кислот изучали в процессе хранения сырья как в регулируемых - $0 \pm 1{ }^{\circ} \mathrm{C}$, так и нерегулируемых условия $\mathrm{x}-4 \pm 6{ }^{\circ} \mathrm{C}$. Показано существенное накопление оксикоричных кислот (до 263\%) при хранении моркови в стандартных условиях и установлено влияние нерегулируемых условий на интенсивность накопления оксикоричных кислот. Проведенный анализ результатов исследования биологической активности основных представителей оксикоричных кислот в растительном сырье - хлорогеновых кислот, показал актуальность дальнейщего изучения динамики указанных веществ при хранении моркови.

Ключевые слова: морковь, ботанические сорта, оксикоричные кислоты, методика определения, валидация, оценка метрологических характеристик, хлорогеновая кислота, исходный уровень в корнеплодах, хранение моркови, динамика биологически активных веществ.

\section{Информация о статье:}

Поступила в редакцию 23.10.2017, принята к печати 24.11.2017

doi: $10.21047 / 1606-4313-2017-16-4-3-8$

Ссылка для цитирования:

Shachek T. M., Marchenkova T. I., Zelenkova E. N. Determination of chlorogenic acids in carrots during storage. // Becтник Международной академии холода. 2017. № 4. С. 3-8. 


\section{Introduction}

Carrot is one of few types of industrial plant raw materials cultivated in Belarus, which correspond to the basic principles of «healthy eating»:

1. The amount of dietary fiber is significant - from 2.4 to $4.4 \%[1]$;

2. The carotene quantity is high (to $17.8 \mathrm{mg}$ per $100 \mathrm{~g}$ of raw material) which causes antioxidant and provitamin $\mathrm{A}$ activity [2];

3. Root crops characteristics of different cultivars and cultivation regions have been reliably established on the basis of long-term domestic studies in terms of the content of macroelements, nitrates and nitrites, toxic elements, etc., [3], which guarantees the safety of manufactured products and allows to predict their quality.

For these reasons, the range of using of carrots as a secondary raw material in functional foods for various population groups has been expanded, for example, as a dry powder in the production of baked goods [4] and flour confectionery products [5]. However, for more efficient and integrated use of this raw material in the manufacture of functional products, it is important to determine and study complementary biologically active substances (BAS), which have not been investigated previously, but present in its composition potentially.

Thus, a number of scientific works devoted to the study of the antioxidant activity of phenolic compounds widespread in nature (substances containing aromatic rings with a hydroxyl group), including phenolic acids, are known. All representatives of this large group (phenolic derivatives) belong to the classes of practically non-toxic substances and, in connection with this, are used in the food industry increasingly.

Interest in them is due to a wide range of their biological effects: medicines based on them are used as antimicrobial, anti-inflammatory, choleretic, diuretic, hypotensive, tonic, astringent and laxatives [6].

The main representatives of phenolic acids of vegetable origin are hydroxycinnamic acids (phenolic compounds with one aromatic ring) - caffeic, ferrulic and sinapic, and their derivatives - glycosides, esters of oxycoric and hydroaromatic acids. Hydroxycinnamic acids in different combinations present almost in all higher plant.

In fruits and vegetables natural phenolic acids are presented by mainly chlorogenic acids. In large quantities, this acid is found in tobacco leaves, in green seeds of coffee, potatoes tubers, etc. Today the expressed cholagogue effect of chlorogenic acid which also inhibits a glucose absorption in an organism is established, than promotes level control of sugar in blood. Except stimulation of CNS activity, chlorogenic acid promotes change of a tone of blood vessels of a brain and heart, is one of the best means of decrease and prevention of exhaustion and a headache [7]. Intensive studying of chlorogenic acid last several years is caused by detection of its ability to inhibit body height of tumors of various etiologies.

Recognition of vegetable raw materials as a source of biological active material perhaps only after detailed studying of concrete connection, assessment of level of its contents in a vegetable matrix and stability at influence of various technology factors. Studying of chlorogenic acids in carrots is relevant also in view of possible increase in its contents in the course of storage of root crops that in turn, leads to synthesis of the bitter substances which also have the phenolic nature [8].

Considering the aforesaid, the assessment of concentration levels of total hydroxycinnamic acids in freshly harvested and stored carrot roots of different botanical grades of the Belarusian growth zone was the purpose of this work. For achievement of a goal, the experiment including two stages was planned and realized:

- the choice of a technique of definition of hydroxycinnamic acids and its validation in the conditions of concrete testing laboratory;

- selection of objects of a research (botanical grade and the region of cultivation of carrots root crops), the choice of the modes of storage of raw materials and definition of hydroxycinnamic acids concentration in the freshly harvested and stored exemplars.

\section{Materials and Methods}

At a stage of theoretical researches the analysis of the techniques for study BAV published in scientific literature was carried out.

For the quantitative determination of hydroxycinnamic acids the original photometric technique, which applied for medicinal vegetable raw materials was used in this work and was modified for the analysis of carrots at steps of sample preparation (sample weight) and preparation of the analyte (volume of the solution being analyzed) (fig. 1) [9].

At the first stage of experimental studies an experiment to validate the chosen procedure for the determination of hydroxycinnamic acids was performed in an accredited testing laboratory for food quality control BSTU. Within the scope of the work, the following validation characteristics were evaluated: repeatability (convergence), reproducibility (intralaboratory) and linearity.

Repeatability (convergence) of the technique was determined within one working day, under the conditions of one laboratory. The operator performed 8 measurements on one equipment. Analytic signals were measured in 48 working samples $(n=2)$, performed with three changing factors: time (4 working days), equipment -2 photoelectrocolorimeter, operator - 3: 1 - technical supervisor of laboratory, 2 master student, 3 - student.

Repeatability and reproducibility parameters were calculated in accordance with the requirements of STB ISO 5725-2-2002 (chapter 7), STB ISO 5725-3-2002 (chapter 8.2). The presence of emissions was verified by the Cochran test. If the statistics value was less than or equal to its $5 \%$ critical value, then the examined position was recognized as correct. In case of the statistics value exceeded $1 \%$ critical value, the study item is given the name of the statistical outlier and it was not taken for further calculations. The critical value for the Cochran test for $p=4$ and $n=2$ is higher than $5 \%-0.906$.

The linearity of the analytical procedure was determined for four levels throughout the concentration range of chlorogenic acid - from 5 to $75 \mathrm{mg} / 100 \mathrm{~g}$ dry weight. For this purpose, working solutions prepared from stock solution by step-by-step dilution - level 4 (Table 1) were used. Four measurements of the optical density of each solution were made with two changing factors: time and operator (see experiment for evaluating intra-laboratory reproducibility). 


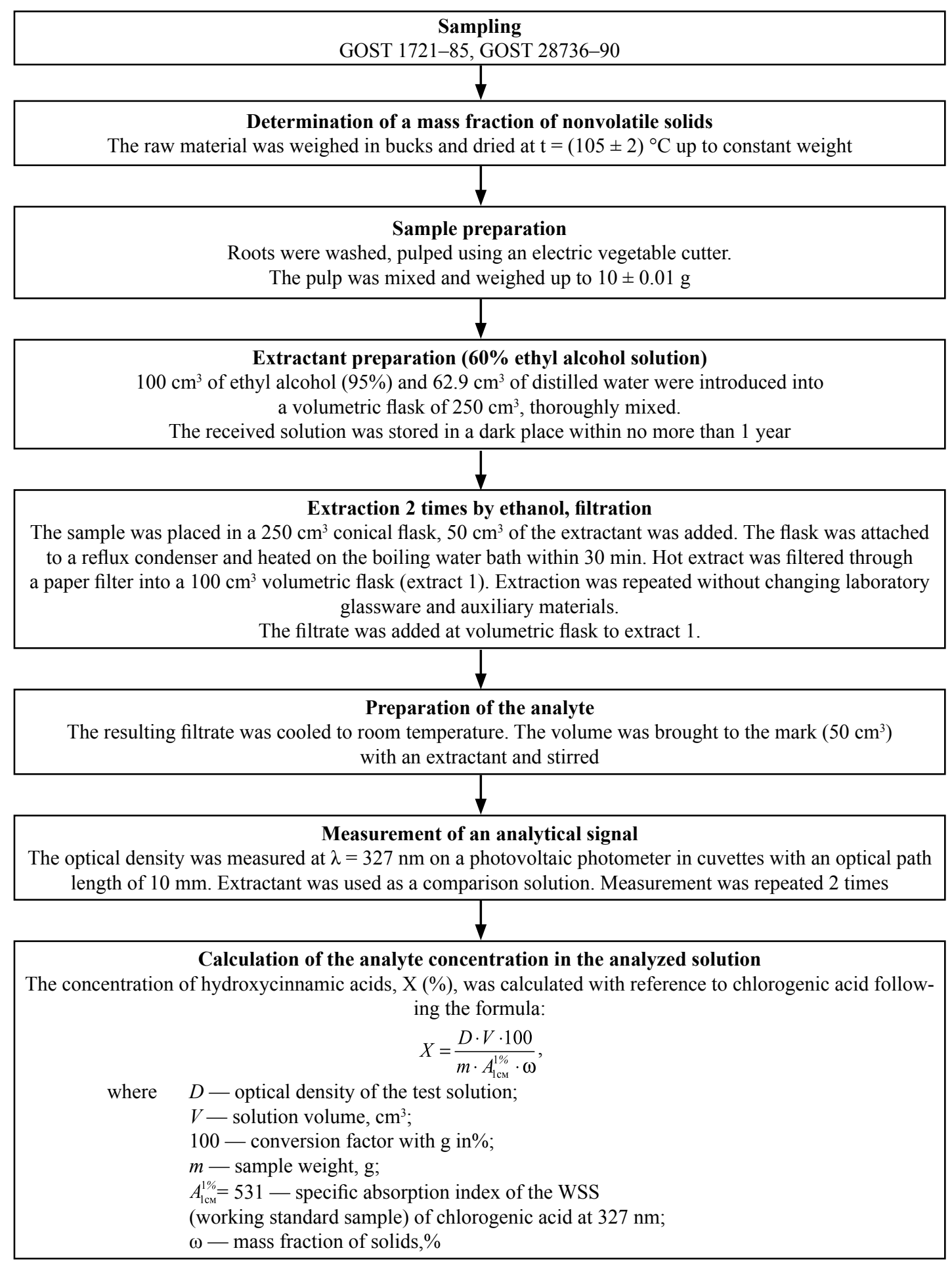

Fig. 1. The scheme of hydroxycinnamic acids analysis in carrots by photometry method

The calibration curve was constructed in coordinates «optical density — concentration of hydroxycinnamic acids in working solutions». The results were carried out by the least squares method using the Microsoft Office Excel program. The criterion of linearity was the correlation coefficient $R^{2}$, which must be at least 0.99 .

After establishing the validation characteristics, the method was used to determine the levels of chlorogenic acids in freshly harvested and stored carrots (crop 2016). Particular carrot cultivars grown in various regions of the Republic of

\section{Scheme of preparation of working solutions for the validation experiment}

\begin{tabular}{|c|c|c|c|}
\hline Level & $\begin{array}{c}\text { Aliquot of the } \\
\text { solution, } \mathrm{cm}^{3}\end{array}$ & $\begin{array}{c}\text { Volume of } \\
\text { solution, } \mathrm{cm}^{3}\end{array}$ & $\begin{array}{c}\text { Concentration of } \\
\text { analyte, \% }\end{array}$ \\
\hline 1 & 5 & 50 & 10 \\
\hline 2 & 20 & 50 & 40 \\
\hline 3 & 35 & 50 & 70 \\
\hline 4 & 50 & 50 & 100 \\
\hline
\end{tabular}


Results of the evaluation of repeatability and intra-laboratory reproducibility

Table 2

\begin{tabular}{|c|c|c|c|c|}
\hline \multirow{2}{*}{ Parameter } & \multicolumn{4}{|c|}{ Concentration range, $\mathrm{mg} / 100 \mathrm{~g}$ dry weight } \\
\cline { 2 - 5 } & $j_{1}$ & $j_{2}$ & $j_{3}$ & $j_{4}$ \\
\cline { 2 - 5 }$S_{\mathrm{r}}, \mathrm{mg} / 100 \mathrm{~g}$ & $5.00-19.99$ & $20.00-39.99$ & $40.00-59.99$ & $00.00-80.00$ \\
\hline$S_{\mathrm{r}, \%}$ & 0.15 & 0.12 & 0.07 & 0.07 \\
\hline$r, \mathrm{mg} / 100 \mathrm{~g}$ & 2.00 & 0.40 & 0.15 & 0.10 \\
\hline$r, \%$ & 0.43 & 0.32 & 0.41 & 0.27 \\
\hline$S_{\mathrm{R}}, \mathrm{mg} / 100 \mathrm{~g}$ & 5.59 & 1.12 & 1.73 & 1.95 \\
\hline$S_{\mathrm{R}}, \%$ & 1.42 & 2.06 & 3.46 & 2.74 \\
\hline$R, \mathrm{mg} / 100 \mathrm{~g}$ & 18.44 & 7.13 & 4.86 & 5.46 \\
\hline$R, \%$ & 3.98 & 5.77 & 9.69 & 7.68 \\
\hline
\end{tabular}

Belarus were selected as the subjects of the study. Samples were following:

- «Dordogne», Soligorsk district, Minsk region;

- «Narbona», Vilejsky district, Minsk region;

- «Shantone», Stolin district, Brest region.

Storage of carrot roots was carried out for 6 months under different temperature regimes:

- regulated - $(0 \pm 1)^{\circ} \mathrm{C}$, specialized vegetable storage;

- unregulated - $(4 \pm 6){ }^{\circ} \mathrm{C}$.

Sampling for research was carried out once a month. In total, 48 freshly harvested and stored carrots were investigated. All the results obtained were processed in accordance with the rules of mathematical statistics.

\section{The results and discussion}

Data of analytical signals measured in working solutions during the validation experiment (under conditions of repeatability and intra-laboratory reproducibility), and their statistical analyses are shown in Table 2.

The data presented in the table indicate that the repeatability characteristics calculated for all four concentration levels did not exceed the acceptance criterion of $10.0 \%$. At the same time, the calculated RMS values and reproducibility limits were 18.44 and $51.63 \%$, when oxycinnamic acids concentration was in the range from 5.0 to $19.9 \mathrm{mg} / 100 \mathrm{~g}$ of $\mathrm{DW}$, which exceeded the established validation criteria of 10.0 and $20.0 \%$, respectively.
The linearity of the method was confirmed and it was indicated that the actual correlation coefficient $(R=1)$ corresponds to the evaluation criterion $(R \geq 0.99)$ (show Fig. 2).

The results showed that for the methodology, which was chosen based on the analysis of the literature data, the validation characteristics, such as repeatability, reproducibility, linearity - meet the accepted evaluation criteria. Thus, the suitability of the photometric method was confirmed for quantitative analysis of hydroxycinnamic acids in carrot in the concentration range of chlorogenic acids - from 20.0 to $80.0 \mathrm{mg} / 100 \mathrm{~g}$ of DW.

Own experimental data of the dynamics of hydroxycinnamic acids in carrot roots stored at temperature $(0 \pm 1){ }^{\circ} \mathrm{C}$ are shown in Fig. 3.

The data (Fig. 3) show that the initial concentration of hydroxycinnamic acids in fresh carrot samples of cultivars Narbon, Dordogne and Chantane was $32.41 \pm 0.16,62.35 \pm 3.05$ and $78.89 \pm 8.26 \mathrm{mg} / 100 \mathrm{~g}$ of DW, respectively. This indicates differences in the accumulation of the studied phenolic compounds in roots of various cultivars. It was established that during the entire storage period, which lasted 120 days, the content of hydroxycinnamic acids increased in all tested carrot samples. And the intensity of this process was higher in the roots of carrot cultivar Narbona, in which the initial level of BAS was the smallest. At the end of the storage period, the content of hydroxycinnamic acids in Narbon, Dordogne and Chantane cultivars was $117.76 \pm 5.85,112.21 \pm 4.07$ and

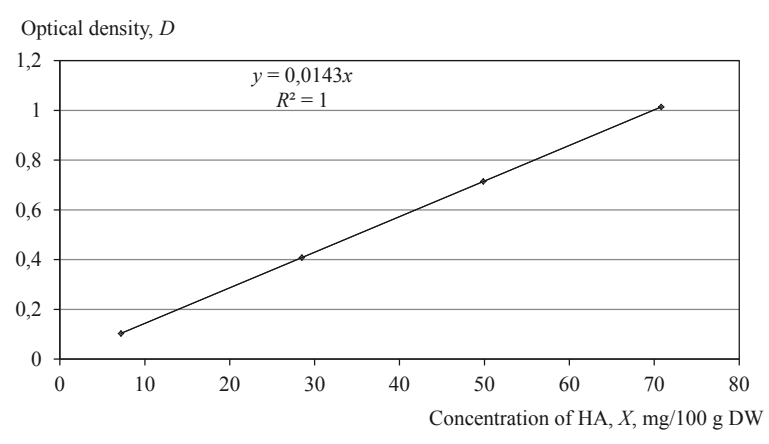

Fig. 2. Calibration curves: analytical signal (D) concentration of hydroxycinnamic acids in working solutions $(\mathrm{mg} / 100 \mathrm{~g} \mathrm{DW})$

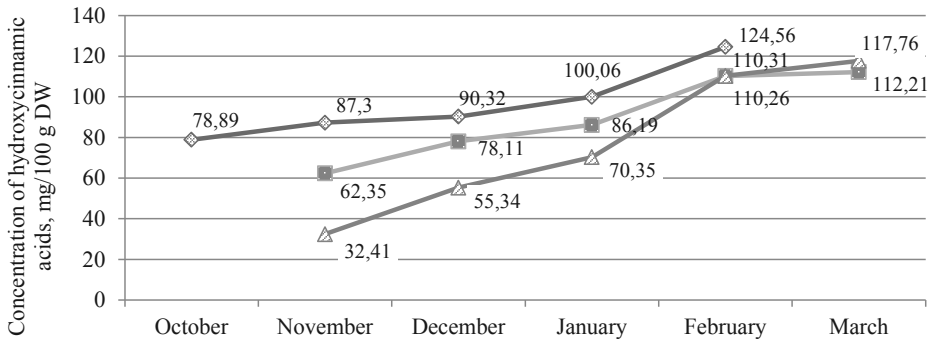

$\diamond$ Shantone $\quad-\quad-$-Dordogne $\quad-$ Narbona

Fig. 3. Change of hydroxycinnamic acids concentration in particular carrot cultivars during storage at standard temperature, $t=(0 \pm 1)^{\circ} \mathrm{C}$ 


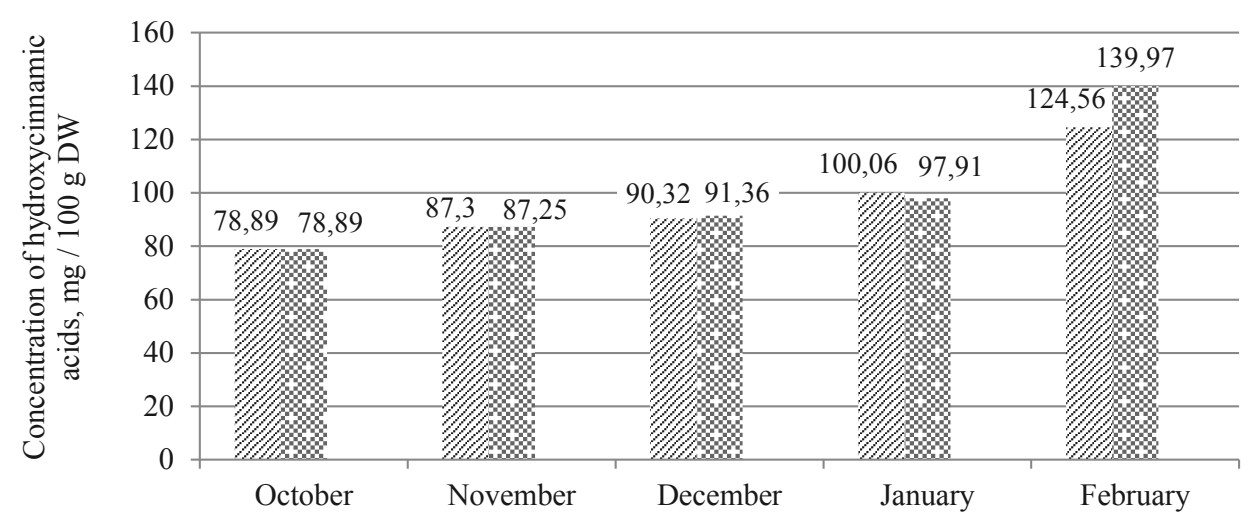

/ Storage temperature $(0 \pm 1)^{\circ} \mathrm{C}$

s Storage temperature $(4 \pm 6)^{\circ} \mathrm{C}$

Fig. 4. Change of hydroxycinnamic acids concentration in carrot roots during storage at different temperatures (on an example of Shantane)

$124.56 \pm 8.13 \mathrm{mg} / 100 \mathrm{~g}$ of DW, respectively, that in its turn, exceeded the original level in 3.6, 1.8 and 1.6 times. The foregoing testifies to the accumulation of free hydroxycinnamic acids in carrots when stored under standard conditions, which corresponds with the data $[10,11]$.

The results of the determination of hydroxycinnamic acids in carrots stored at different temperature regimes - $(0 \pm 1)$ and $(4 \pm 6){ }^{\circ} \mathrm{C}$, are shown in Fig. 4. They showed the following.

The gradual increase in the baseline level of the BAS studied $(78.89 \pm 8.26 \mathrm{mg} / 100 \mathrm{~g} \mathrm{DW})$ was detected during the first three months for all root crops stored at $(0 \pm 1)$ and $(4 \pm 6){ }^{\circ} \mathrm{C}$. At the final stage of the experiment (90-120 days), when carrots were storaged under unregulated conditions $(4 \pm 6){ }^{\circ} \mathrm{C}$, the content of hydroxycinnamic acids has increased by $43.1 \%$, and in regulated ones - by $24.5 \%$ (Fig. 3). Consequently, after 120 days the initial level increased by $57.9 \%$ in carrots stored at $(0 \pm 1){ }^{\circ} \mathrm{C}$, and the increase in the number of hydroxycinnamic acids was $77.4 \%$ in carrots stored at - $(4 \pm 6)^{\circ} \mathrm{C}$,

\section{Conclusions}

Thus, the results of the experimental studies are folowing:

- new data on the content of hydroxycinnamic acids in carrot cultivars of Narbona, Dordogne and Shantanu grown in Belarus, were obtained;

\section{Литература}

1. Sara A. Arscott and Sherry A. Tanumihardjo. Carrots of Many Colors Provide Basic Nutrition and Bioavailable Phytochemicals Acting as a Functional Food // Comprehensive Reviews in Food Science and Food Safety. 2010. No 9 (2). P. 223-239.

2. Налобова Ю. М., Бохан А. И. Характеристика сортов моркови столовой по хозяйственно ценным признакам // Овощеводство. 2012. Вып. 20. С. 154-161.

3. Шачек T. М. Контроль качества и безопасности консервов для детского питания из моркови и яблок на основе применения анализа риска: дис... канд. техн. наук: 05.18.01. Москва, 2010. 244 с.
- photometric method for the analysis of hydroxycinnamic acids in carrots was modified and the suitability of this technique was confirmed in the accredited testing laboratory for food quality control of BSTU;

- data on the dynamics of hydroxycinnamic acids during storage of carrots were obtained and they indicate:

1) the content of BAS increases in the carrot roots stored under standard conditions $-(0 \pm 1){ }^{\circ} \mathrm{C}$;

2) the stability of temperature influences on the intensity of accumulation of hydroxycinnamic acids in carrots. The initial level of hydroxycinnamic acids $(78.89 \pm 8.26 \mathrm{mg} / 100 \mathrm{~g} \mathrm{DW})$ in cultivar Shantane increased 1.6 and 1.8 times during the storage at temperatures $(0 \pm 1){ }^{\circ} \mathrm{C}$ and $(4 \pm 6){ }^{\circ} \mathrm{C}$ respectively.

The modified photometric method for the determination of hydroxycinnamic acids in fresh carrots, which was described in the article, will be able to be applied in plant laboratories for assessing the quality of vegetable raw materials for processing.

Experimental studies the levels of hydroxycinnamic acids in freshly harvested and stored carrot roots will be continued for other cultivars of raw materials, grown in the Republic of Belarus. The results will be included in the database on the nutritional value of domestic raw materials, which will optimize the timing and directions of its processing — canned food of the general group, baby food, etc., as well as predict the foodstuff quality.

\section{References}

1. Sara A. Arscott and Sherry A. Tanumihardjo. Carrots of Many Colors Provide Basic Nutrition and Bioavailable Phytochemicals Acting as a Functional Food. Comprehensive Reviews in Food Science and Food Safety. 2010. No 9 (2). P. 223-239.

2. Nalobova Y. M., Bokhan A. I. Characteristics of varieties of carrots of a dining room on economically valuable traits. Vegetablegrowing. Minsk, 2012. Issue. 20. P. 154-161. (in Russian)

3. Shachek T. M. Quality control and safety of canned food for baby food from carrots and apples based on the application of risk analysis: dis. cand. technical. sciences: 05.18.01. Moscow, 2010. 244 p. (in Russian) 
4. Типсина Н. Н., Типсин Е. А. Использование порошка моркови в пищевой промышленности. // Вестник Красноярского государственного аграрного университета. 2014. № 4. С. 257-261.

5. Перфилова О. В., Митрохин М. А. Использование порошков из плодоовощных выжимок с целью расширения ассортимента мучных кондитерских изделий. // Достижения науки и техники АПК. 2008. № 8. С. 48-50.

6. Моисеев Д. В. Определение фенольных кислот в растениях методом ВЖЭХ. // Химия растительного сырья. 2014. № 3. C. 171-174.

7. Бельтюкова С. В., Степанова А. А., Ливенцуова Е. О. Антиоксиданты в пищевых продуктах и методы их определения. // Вісник Одеського національного університету. Хімія. 2014. T. 19, № 4. С. 16-31.

8. Джум Т. А., Исагулян Э. А. Изменение содержания хлорогеновой кислоты при хранении моркови. // Известия ВУЗОВ. Пищевая технология. 2007. № 2. С. 101.

9. Марченкова Т. И., Шачек Т. М. Модифицированные методики определения пигментообразующих и фенольных соединений в моркови. // 68-я НТК учащихся, студентов и магистрантов, 17-22 апреля, Минск: сборник научных работ. Часть 2. - Минск: БГТУ, 2017. С. 225-227.

10. Абрамова Я. И., Чучалин В. С., Калинкина Г. И., Коломиeu H. Э. Валидация методики количественного определения гидроксикоричных кислот в желчегонном сборе № 2. // Химия растительного сырья. 2012. № 3. С. 157-161.

11. Обломий Р. Н., Исагулян Э. А. Динамика изменения оксикоричных кислот моркови при хранении. // Известия вузов. Пищевая технология. 2010. № 5-6. С. 13-14.

\section{Сведения об авторах}

\section{Шачек Татьяна Михайловна}

к.т. н., доцент кафедры физико-химических методов сертификации продукции БГТУ,

Республика Беларусь, 220006, г. Минск, ул. Свердлова, 13а, shachek@tut.by

\section{Марченкова Татьяна Ивановна}

магистрант кафедры физико-химических методов сертификации продукции БГТУ,

Республика Беларусь, 220006, г. Минск, ул. Свердлова, 13а, marchelitta@tut.by

\section{Зеленкова Елена Николаевна}

ассистент кафедры физико-химических методов сертификации продукции БГТУ,

Республика Беларусь, 220006, г. Минск, ул. Свердлова, 13а, elena.taras@mail.ru
4. Tipsina N. N., Tipsin E. A. The use of carrot powder in the food industry. Bulletin of the Krasnoyarsk State Agrarian University. 2014. No 4. P. 257-261. (in Russian)

5. Perfilova O. V., Mitrokhin M. A. Use of powders from fruit and vegetable extracts to expand the assortment of flour confectionery. Achievements of science and technology of the agroindustrial complex. 2008. No. 8. P. 48-50. (in Russian)

6. Moiseev D. V. Determination of phenolic acids in plants by the HPLC method. Chemistry of plant raw materials. 2014. No. 3. P. 171-174. (in Russian)

7. Beltyukova S. V., Stepanova A. A., Liventsova E. O. Antioxidants in food products and methods for their determination. Visnik Odes'kogo natsional'nogo universitetu. Khimiya. 2014. Vol. 19, Issue. 4. P. 16-31.

8. Dzhum T. A., Isagulyan E. A. Change in the content of chlorogenic acid in the storage of carrots. Izvestiya Vuzov. Food technology. 2007. No 2. P. 101. (in Russian)

9. Marchankava T. I., Shachek T. M. Modified methods for the determination of pigment-forming and phenolic compounds in carrots. 68th scientific and technical conference of students, students and undergraduates, April 17-22, Minsk: a collection of scientific works, Part 2. Minsk: BSTU, 2017. P. 225-227. (in Russian)

10. Abramova Y. I, Chuchalin V. S., Kalinkina G. I., Kolomiets N. E. Validation of the procedure for the quantitative determination of hydroxycinnamic acids in choleretic collection No. 2. Chemistry of plant raw materials. 2012. No. 3. P. 157-161. (in Russian)

11. Oblomii R. N., Isagulyan E. A. Dynamics of changes in oxycinnamic acids of carrots during storage. Izvestiya Vuzov. Food technology. 2010. No. 5-6. P. 13-14. (in Russian)

\section{Information about authors}

\section{Shachek Tatyana Mikhailovna}

Ph.D., associate professor of Department of physico-chemical methods of products certification BSTU, Republic of Belarus, 220006, Minsk, Sverdlova St., 13a, shachek@tut.by

\section{Marchankava Tatsiana Ivanovna}

undergraduate of Department of physico-chemical methods of products certification BSTU, Republic of Belarus,

220006, Minsk, Sverdlova St., 13a,

marchelitta@tut.by

\section{Zelenkova Elena Nikolaevna}

assistant of Department of physico-chemical methods of products certification BSTU, Republic of Belarus, 220006, Minsk, Sverdlova St., 13a, elena.taras@mail.ru 